\title{
Mechanical AndTribological Characterization Of Short Fibers Reinforced Polymer Composites
}

\author{
Prof.AshishKhandelwal ${ }^{1}$, AbhishekChoubey ${ }^{2}$ \\ ${ }^{1}$ Assistant Professor and, Faculty of CEC Bilaspur (CG). \\ ${ }^{2}$ Student of M.E. CEC Bilaspur (CG).
}

\begin{abstract}
Solid particle erosion of polymer composites is a complex surface damage process, strongly affected by material properties and operational conditions. The present research work is undertaken to study the development, characterization and erosion wear performance of two different categories of fibers when reinforced in polymers. One of the two fiber is well known synthetic fiber i.e. glass fiber which is commercially used by many industries and the other fiber will be a natural fiber i.e. banana fiber which will be the new attempt in the present investigation. In both the above cases matrix material will remain epoxy. Attempts have been made to explore the possible use of a natural fiber as filler material in composites. To make an assessment of their (banana fiber) reinforcing potential in terms of wear performance and mechanical properties, various physical, mechanical and wear performance of the composites are studied in details and its comparison with a similar set of composites with glass fiber as a filler material is reported. The reported data are purely extracted from experimental measurement under controlled laboratory conditions. From the performed experiments it can be seen that a banana fiber can successfully replace the glass fiber as far as wear performance in concerned, as the study indicates that erosion wear performance of banana fiber based composites is better than that of the glass fiber reinforced composites. Banana fiber is also having a very low specific gravity, so their composites show very low density as compared to glass fiber reinforced composites. From other mechanical characterization it can be said that, in strength point of view, banana fiber-epoxy composites are not very much behind its counterparts glass fiber-epoxy composites.
\end{abstract}

Key words: - Glass fibre,matrixmaterial,bananafibre,epoxy resin and composite material.

\section{Composite Materials}

\section{INTRODUCTION}

Composites are combinations of two materials in which one of the materials, called the reinforcing phase, is in the form of fiber sheets or particles and are embedded in the other material called the matrix phase. Composite materials have successfully substituted the traditional materials in several light weight and high strength applications.

\section{Types of Composite Materials}

Broadly, composite materials can be classified into three groups on the basis of matrix material. They are:

a) Metal Matrix Composites (MMC)

b) Ceramic Matrix Composites (CMC)

\section{LITERATURE REVIEW}

A treatise on glass fiber and banana fiber reinforced polymer composites has been given illustrating the research findings. The physical behavior, mechanical behavior and wear characteristics of different composites as reported in existing literature have been cited.

A great deal of work has been done by many researchers on synthetic fiber based polymer composites. Jawaid and Khalil [5] presented review that deals with the recent development of cellulosic/cellulosic and cellulosic/synthetic fibers based reinforced hybrid composites. Marom et al. [6] focused on the elastic properties of synthetic fiber-reinforced polymer composite materials that pertain to biomedical applications and demonstrates the range of stiffness obtainable through selection of constituents and by choice of angle of reinforcement. Jansons et al. [7] studied on the effect of water absorption, elevated temperatures and fatigue on the mechanical properties of carbon-fiber-reinforced epoxy composites. Kutty and Nando [8] studied the effect of processing parameters on the mechanical properties of short Kevlar aramid fiber-thermoplastic polyurethane composite and observed that processing parameters like nip gap, friction ratio and mill roll temperature have extreme influence on the fiber orientation and hence on the mechanical properties of short Kevlar aramid fiberthermoplastic polyurethane composite. Cho et al. [9] studied the mechanical behavior of carbon fiber/epoxy composites and found that the composites reinforced with nanoparticles improved mechanical properties such as 
enhanced compressive strength and enplane shear properties. Chauhan et al. [10] studied on the effect of fiber loading on mechanical properties, friction and wear behavior of vinyl ester composites under dry and water lubricated conditions and reported that the density of composite specimens is affected marginally by increasing the fiber content.

\section{MATERIALS AND METHODS}

Matrix materials are of different types like metals, ceramics and polymers. Polymer matrices are most commonly used because of cost efficiency, ease of fabricating complex parts with less tooling cost and they also have excellent room temperature properties when compared to metals and ceramic matrices. The most commonly used thermoset resins are epoxy, polyester, vinyl ester and phenolics.

Filler Material - 1 : ( Short Glass Fiber)It is one of the most widely used reinforcements with polymers. Fiber glass is a lightweight, extremely strong, and robust material.

Table 2.Typical properties of glass fibres

\begin{tabular}{|l|l|l|l|l|}
\hline Material & \multicolumn{1}{|c|}{ Density $\left(\mathbf{g} / \mathbf{c m}^{\mathbf{3}}\right)$} & Tensile Strength (MPa) & $\begin{array}{c}\text { Young's Modulus } \\
(\mathbf{G P a})\end{array}$ & $\mathbf{C T E}\left(\mathbf{1 0}^{\mathbf{- 6}} \mathbf{K}\right)$ \\
\hline S-glass & 2.55 & 3400 & 73 & 5.0 \\
\hline E-glass & 2.49 & 4400 & 86 & 5.6 \\
\hline
\end{tabular}

Filler Material - 2 :( Short Banana Fiber)

In India, natural fibres such as jute, coir, sisal, pineapple, ramie, bamboo, banana etc., are available in plenty. Sisal and banana fibres are cellulose-rich (> 65\%) and have comparable tensile strength, modulus and failure strain with other cellulose-rich fibres like jute and flax.

Table 3.Cultivation details of Banana (Source: FAOSTAT)

\begin{tabular}{|l|l|l|l|}
\hline & Area (ha) & Production (Ton) & Average Production (t/ha) \\
\hline World & 4544702 & 69280 & 15.2 \\
\hline India & 529700 & 16225 & 30.63 \\
\hline
\end{tabular}

Table 4.Typical properties of banana fibers

\begin{tabular}{|l|l|l|l|l|l|}
\hline Material & Density $\left(\mathrm{g} / \mathrm{cm}^{3}\right)$ & $\begin{array}{l}\text { Tensile Strength } \\
(\mathrm{MPa})\end{array}$ & $\begin{array}{l}\text { Young's Modulus } \\
(\mathrm{GPa})\end{array}$ & $\begin{array}{l}\text { \% Elongation at } \\
\text { break }\end{array}$ \\
\hline Banana fiber & 1.35 & $400-600$ & $16-20$ & 5.9 \\
\hline
\end{tabular}

Experimental details

Composite Fabrication

Set 1Epoxy Composites filled with short glass fibers

Low temperature curing epoxy resin (LY 556) and corresponding hardener (HY951) are mixed in a ratio of 10:1 by weight as recommended.

Table 5.Epoxy composites filled with short glass fiber (Set 1)

\begin{tabular}{|c|c|}
\hline S.No. & Composition \\
\hline 1 & Epoxy $+0 \mathrm{wt} \%$ Short glass fiber \\
\hline 2 & Epoxy $+5 \mathrm{wt} \%$ Short glass fiber \\
\hline 3 & Epoxy $+10 \mathrm{wt} \%$ Short glass fiber \\
\hline 4 & Epoxy $+15 \mathrm{wt} \%$ Short glass fiber \\
\hline 5 & Epoxy $+20 \mathrm{wt} \%$ Short glass fiber \\
\hline 6 & Epoxy $+25 \mathrm{wt} \%$ Short glass fiber \\
\hline 7 & Epoxy $+30 \mathrm{wt} \%$ Short glass fiber \\
\hline
\end{tabular}

Set 2Epoxy Composites filled with short banana fiber

In a similar manner, epoxy composites of 7 more different compositions (Table 6.) were made with short banana fiber. For each composition, the composites were cast in plastic moulds so as to get the similar rectangular specimens (length $150 \mathrm{~mm}$, width $20 \mathrm{~mm}$, thickness $4 \mathrm{~mm}$ ).

Table 6.Epoxy composites filled with short banana fiber (Set 2)

$$
\text { Composition }
$$




\begin{tabular}{|c|c|}
\hline Epoxy +0 wt \% Short banana fiber \\
\hline Epoxy +5 wt \% Short banana fiber \\
\hline Epoxy +10 wt \% & Short banana fiber \\
\hline Epoxy +15 wt \% & Short banana fiber \\
\hline Epoxy +20 wt \% & Short banana fiber \\
\hline Epoxy +25 wt \% & Short banana fiber \\
\hline Epoxy +30 wt \% & Short banana fiber \\
\hline
\end{tabular}

\section{Physical characterization}

\section{Density and volume fraction of voids}

Density of a composite depends on the relative proportion of matrix and reinforcing materials and it is one of the most important factors for determining the properties of the composites. The theoretical density $\left(\rho_{c t}\right)$ of composite materials in terms of weight fractions of different constituents can easily be obtained using the following equation

$$
\rho_{c t}=1 /\left\{\left(\frac{w_{f}}{\rho_{f}}\right)+\left(\frac{w_{m}}{\rho_{m}}\right)\right\}
$$

where, $w$ and $\rho$ represent the weight fraction and density respectively. The suffixes $f$ and $m$ stand for the filler and matrix respectively in a composite with single filler.

The actual density $\left(\rho_{c e}\right)$ of the composite can be determined experimentally by the Archimedes principle or water displacement technique (ASTM D 792-91). The volume fraction of voids $\left(v_{v}\right)$ in the composites is calculated by using the following equation:

$$
v_{v}=\left(\rho_{c t}-\rho_{c e}\right) / \rho_{c t}
$$

\section{Mechanical characterization \\ Micro-hardness}

Micro-hardness measurement was done using a Leitz micro-hardness tester A diamond indenter, in the form of a right pyramid with a square base and an angle $136^{\circ}$ between opposite faces, was forced into the material under a load $F$. The two diagonals $X$ and $Y$ of the indentation left on the surface of the material after removal of the load were measured and their arithmetic mean was calculated. In the present study, the load considered $F=0.2454 \mathrm{~N}$ and Vickers hardness number is calculated using the following equation.

$$
\begin{aligned}
& H_{v}=0.1889 \frac{F}{L^{2}} \\
& \text { where, } \quad L=\frac{X+Y}{2} \text { (c) }
\end{aligned}
$$

\section{Compressive strength}

The cured composite samples of required dimension (length $10 \mathrm{~mm}$, diameter $10 \mathrm{~mm}$ ), were used for the uniaxial compression test as per ASTM D 695 standard.

\section{Tensile strength}

The cured dog bone shaped composite samples (prepared from the rectangular slabs) of required dimension (length $150 \mathrm{~mm}$, end width $20 \mathrm{~mm}$ and mid width $12 \mathrm{~mm}$ ) were used for the tensile test as per ASTM E 1309 standard.

\section{Flexural Strength}

The determination of flexural strength is an important characterization of any structural material. Impact

\section{strength}

Low velocity instrumented impact tests are carried out on composite specimens. The tests are done as per ASTM D 256 using an impact tester .

\section{TRIBOLOGICAL CHARACTERIZATION}




\section{Solid particle erosion test apparatus}

Solid particle erosion (SPE) is usually simulated in laboratory by one of two methods. The 'sand blast' method, where particles are carried in an air flow and impacted onto a stationary target and the 'whirling arm' method, where the target is spun through a chamber of falling particles.

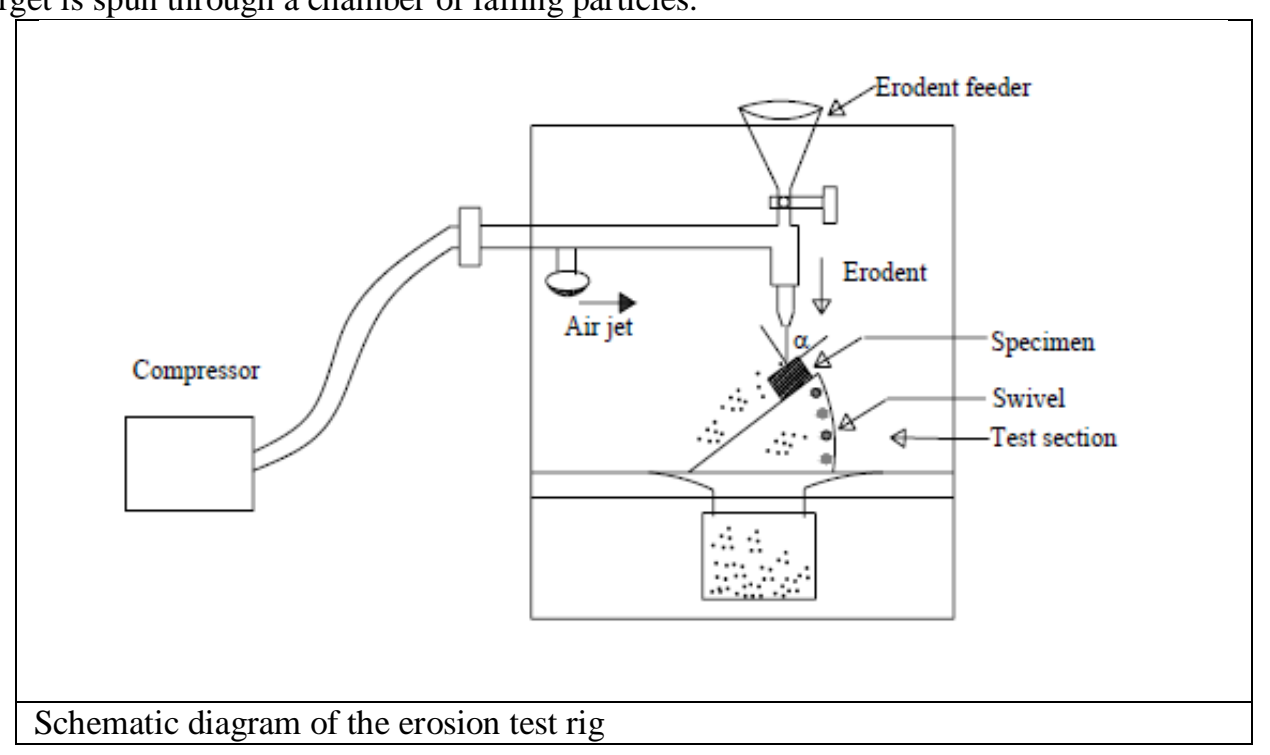

In the present investigation, an erosion apparatus (self-made) of the 'sand blast' type is used.

\section{TAGUCHI EXPERIMENTAL DESIGN}

In any experimental research, since test procedures are generally expensive and time consuming, the need to satisfy the design objectives with the least number of tests is clearly an important requirement. In this context, Taguchi method provides the designer with a systematic and efficient approach for experimentation to determine near optimum settings of design parameters for performance and cost.

Table 7.:Parameter settings for erosion test

\begin{tabular}{|c|c|c|c|}
\hline Command factors & Abbreviation & \multicolumn{2}{|c|}{ Constant Parameters } \\
\hline Impact velocity & Factor A & Erodent & Silica sand \\
\hline Filler content & Factor B & Erodent feed rate $(\mathrm{g} / \mathrm{min})$ & $10.0 \square \square \square \square \square$ \\
\hline Erodent temperature & Factor $\mathrm{C}$ & Nozzle Diameter (mm) & $3 \mathrm{~mm}$ \\
\hline Impingement angle & Factor D & Length of nozzle & $80 \mathrm{~mm}$ \\
\hline Stand-off distance & Factor $\mathrm{E}$ & & \\
\hline Erodent size & Factor $\mathrm{F}$ & & \\
\hline
\end{tabular}

Table 8.:Control factors and their selected levels

\begin{tabular}{|l|c|c|c|c|}
\hline \multirow{2}{*}{\multicolumn{1}{|c|}{ Command factors }} & \multicolumn{4}{c|}{ Level } \\
\cline { 2 - 5 } & I & II & III & Units \\
\hline Factor A : Impact velocity & 30 & 40 & 50 & $\mathrm{~m} / \mathrm{sec}$ \\
\hline Factor B : Filler content & 0 & 15 & 30 & wt. \% \\
\hline Factor C : Erodent temperature & 40 & 50 & 60 & ${ }^{\circ} \mathrm{C}$ \\
\hline Factor D : Impingement angle & 30 & 60 & 90 & degree \\
\hline Factor E : Stand-off distance & 60 & 70 & 80 & $\mathrm{~mm}$ \\
\hline Factor F : Erodent size & 300 & 450 & 600 & $\mu \mathrm{m}$ \\
\hline
\end{tabular}

The selected parameters viz., impact velocity, filler content, erodent temperature, stand-off distance, impingement angle and erodent size, each at three levels, are considered in this study. These six parameters each at three levels would require $36=729$ runs in a full factorial experiment whereas Taguchi's experimental approach reduces it to 27 runs only offering a great advantage. The plan of the experiments as shown in Table 3.5 is as follows: the first, second, fifth, ninth, tenth and twelfth columns are assigned to impact velocity (A), filler content (B), erodent temperature (C), impingement angle (D), stand-off distance (E) and erodent size (F) respectively. The third and fourth column are assigned to (A $\square \mathrm{B}) 1$ and (A $\square \mathrm{B}$ )2 respectively to estimate interaction between impact velocity (A) and filler content (B), the sixth and seventh column are assigned to 
(B $\square \mathrm{C}) 1$ and (B $\square \mathrm{C}) 2$ respectively to estimate ineraction between filler content (B) and erodent temperature (C), the eighth and eleventh column are assigned to (A $\square \mathrm{C}) 1$ and (A $\square \mathrm{C}$ ) 2 respectively to estimate interaction between the impact velocity (A) and erodent temperature (C) and the remaining columns are used to estimate experimental errors.

Table 9: Orthogonal array for L27 $\left(3^{13}\right)$ Taguchi Design

\begin{tabular}{|c|c|c|c|c|c|c|c|c|c|c|c|c|c|}
\hline $\begin{array}{l}\text { Test } \\
\text { run }\end{array}$ & $\begin{array}{l}\mathbf{1} \\
\mathbf{A}\end{array}$ & $\begin{array}{l}2 \\
\text { B }\end{array}$ & $\begin{array}{c}\mathbf{3} \\
(\mathbf{A} \times \mathbf{B})_{1}\end{array}$ & $\begin{array}{c}4 \\
(\mathrm{~A} \times \mathrm{B})_{2}\end{array}$ & $\begin{array}{l}5 \\
\text { C }\end{array}$ & $\begin{array}{c}\mathbf{6} \\
(\mathrm{B} \times \mathrm{C})_{1}\end{array}$ & $\begin{array}{c}7 \\
(\mathbf{B} \times \mathrm{C})_{2}\end{array}$ & $\begin{array}{c}8 \\
(A \times C) \\
1\end{array}$ & $\begin{array}{l}9 \\
\text { D }\end{array}$ & $\begin{array}{l}10 \\
\mathbf{E}\end{array}$ & $\begin{array}{c}11 \\
(\mathrm{~A} \times \mathrm{C}) \\
2\end{array}$ & 12 & 13 \\
\hline 1 & 1 & 1 & 1 & 1 & 1 & 1 & 1 & 1 & 1 & 1 & 1 & 1 & 1 \\
\hline 2 & 1 & 1 & 1 & 1 & 2 & 2 & 2 & 2 & 2 & 2 & 2 & 2 & 2 \\
\hline 3 & 1 & 1 & 1 & 1 & 3 & 3 & 3 & 3 & 3 & 3 & 3 & 3 & 3 \\
\hline 4 & 1 & 2 & 2 & 2 & 1 & 1 & 1 & 2 & 2 & 2 & 3 & 3 & 3 \\
\hline 5 & 1 & 2 & 2 & 2 & 2 & 2 & 2 & 3 & 3 & 3 & 1 & 1 & 1 \\
\hline 6 & 1 & 2 & 2 & 2 & 3 & 3 & 3 & 1 & 1 & 1 & 2 & 2 & 2 \\
\hline 7 & 1 & 3 & 3 & 3 & 1 & 1 & 1 & 3 & 3 & 3 & 2 & 2 & 2 \\
\hline 8 & 1 & 3 & 3 & 3 & 2 & 2 & 2 & 1 & 1 & 1 & 3 & 3 & 3 \\
\hline 9 & 1 & 3 & 3 & 3 & 3 & 3 & 3 & 2 & 2 & 2 & 1 & 1 & 1 \\
\hline 10 & 2 & 1 & 2 & 3 & 1 & 2 & 3 & 1 & 2 & 3 & 1 & 2 & 3 \\
\hline 11 & 2 & 1 & 2 & 3 & 2 & 3 & 1 & 2 & 3 & 1 & 2 & 3 & 1 \\
\hline 12 & 2 & 1 & 2 & 3 & 3 & 1 & 2 & 3 & 1 & 2 & 3 & 1 & 2 \\
\hline 13 & 2 & 2 & 3 & 1 & 1 & 2 & 3 & 2 & 3 & 1 & 3 & 1 & 2 \\
\hline 14 & 2 & 2 & 3 & 1 & 2 & 3 & 1 & 3 & 1 & 2 & 1 & 2 & 3 \\
\hline 15 & 2 & 2 & 3 & 1 & 3 & 1 & 2 & 1 & 2 & 3 & 2 & 3 & 1 \\
\hline 16 & 2 & 3 & 1 & 2 & 1 & 2 & 3 & 3 & 1 & 2 & 2 & 3 & 1 \\
\hline 17 & 2 & 3 & 1 & 2 & 2 & 3 & 1 & 1 & 2 & 3 & 3 & 1 & 2 \\
\hline 18 & 2 & 3 & 1 & 2 & 3 & 1 & 2 & 2 & 3 & 1 & 1 & 2 & 3 \\
\hline 19 & 3 & 1 & 3 & 2 & 1 & 3 & 2 & 1 & 3 & 2 & 1 & 3 & 2 \\
\hline 20 & 3 & 1 & 3 & 2 & 2 & 1 & 3 & 2 & 1 & 3 & 2 & 1 & 3 \\
\hline 21 & 3 & 1 & 3 & 2 & 3 & 2 & 1 & 3 & 2 & 1 & 3 & 2 & 1 \\
\hline 22 & 3 & 2 & 1 & 3 & 1 & 3 & 2 & 2 & 1 & 3 & 3 & 2 & 1 \\
\hline 23 & 3 & 2 & 1 & 3 & 2 & 1 & 3 & 3 & 2 & 1 & 1 & 3 & 2 \\
\hline 24 & 3 & 2 & 1 & 3 & 3 & 2 & 1 & 1 & 3 & 2 & 2 & 1 & 3 \\
\hline 25 & 3 & 3 & 2 & 1 & 1 & 3 & 2 & 3 & 2 & 1 & 2 & 1 & 3 \\
\hline 26 & 3 & 3 & 2 & 1 & 2 & 1 & 3 & 1 & 3 & 2 & 3 & 2 & 1 \\
\hline 27 & 3 & 3 & 2 & 1 & 3 & 2 & 1 & 2 & 1 & 3 & 1 & 3 & 2 \\
\hline
\end{tabular}

The experimental observations are further transformed into signal-to-noise $(\mathrm{S} / \mathrm{N})$ ratios. There are several $\mathrm{S} / \mathrm{N}$ ratios available depending on the type of characteristics as given by following equations:

'Smaller- the- better' characteristic: $\frac{S}{N}=-10 \log \frac{1}{n}\left(\sum y^{2}\right)$

'Nominal- the- better' characteristics: $\frac{S}{N}=-10 \log \frac{1}{n}\left(\sum \frac{\bar{Y}}{S_{y}^{2}}\right)$

'Larger- the- better' characteristics: $\frac{S}{N}=-10 \log \frac{1}{n}\left(\sum \frac{1}{y^{2}}\right)$

where, ' $\mathrm{n}$ ' is the number of observations and ' $\mathrm{y}$ ' is the observed data. The $\mathrm{S} / \mathrm{N}$ ratio for minimum wear rate comes under 'smaller is better' characteristic, which can be calculated as logarithmic transformation of the loss function by using Equation (d).

\section{PHYSICAL AND MECHANICAL PROPERTIES OF THE COMPOSITES}

Density and Void Fraction

The theoretical and measured densities along with the corresponding volume fraction of voids in the epoxy-glass fiber and epoxy- banana fiber composites are presented in Tables 4.1 and 4.2 respectively. 
Table 10 Measured and theoretical densities of the composites (Epoxy filled with short glass fiber)

\begin{tabular}{|c|c|c|c|}
\hline Composites & $\begin{array}{c}\text { Measured } \\
\text { density } \\
\text { (gm/cc) }\end{array}$ & $\begin{array}{c}\text { Theoretical } \\
\text { density } \\
(\mathbf{g m} / \mathbf{c c})\end{array}$ & $\begin{array}{c}\text { Void } \\
\text { fraction } \\
(\%)\end{array}$ \\
\hline Neat Epoxy ( hardened) & 1.1 & - & - \\
\hline Epoxy + short glass fiber ( 5 wt \%) & 1.119 & 1.131 & 1.06 \\
\hline Epoxy + short glass fiber ( 10 wt \%) & 1.146 & 1.165 & 1.63 \\
\hline Epoxy + short glass fiber ( 15 wt \%) & 1.172 & 1.201 & 2.41 \\
\hline Epoxy + short glass fiber ( 20 wt \%) & 1.195 & 1.238 & 3.47 \\
\hline Epoxy + short glass fiber ( 25 wt \%) & 1.214 & 1.279 & 5.08 \\
\hline Epoxy + short glass fiber ( 30 wt \%) & 1.235 & 1.322 & 6.58 \\
\hline
\end{tabular}

Table 11. Measured and Theoretical densities of the composites(Epoxy filled with short bananafiber)

\begin{tabular}{|c|c|c|c|}
\hline Composites & $\begin{array}{c}\text { Measured } \\
\text { density } \\
(\mathrm{gm} / \mathrm{cc})\end{array}$ & $\begin{array}{c}\text { Theoretical } \\
\text { density } \\
(\mathrm{gm} / \mathrm{cc})\end{array}$ & $\begin{array}{c}\text { Void } \\
\text { fraction } \\
(\%)\end{array}$ \\
\hline Neat Epoxy ( hardened) & 1.1 & - & - \\
\hline Epoxy + short banana fiber $(5 \mathrm{wt} \%)$ & 1.107 & 1.110 & 0.27 \\
\hline Epoxy + short banana fiber ( 10 wt $\%$ ) & 1.114 & 1.121 & 0.62 \\
\hline Epoxy + short banana fiber ( 15 wt \% ) & 1.120 & 1.131 & 0.97 \\
\hline Epoxy + short banana fiber ( 20 wt \% ) & 1.127 & 1.142 & 1.31 \\
\hline Epoxy + short banana fiber ( 25 wt \% ) & 1.133 & 1.153 & 1.73 \\
\hline Epoxy + short banana fiber ( 30 wt \% ) & 1.138 & 1.165 & 2.31 \\
\hline
\end{tabular}

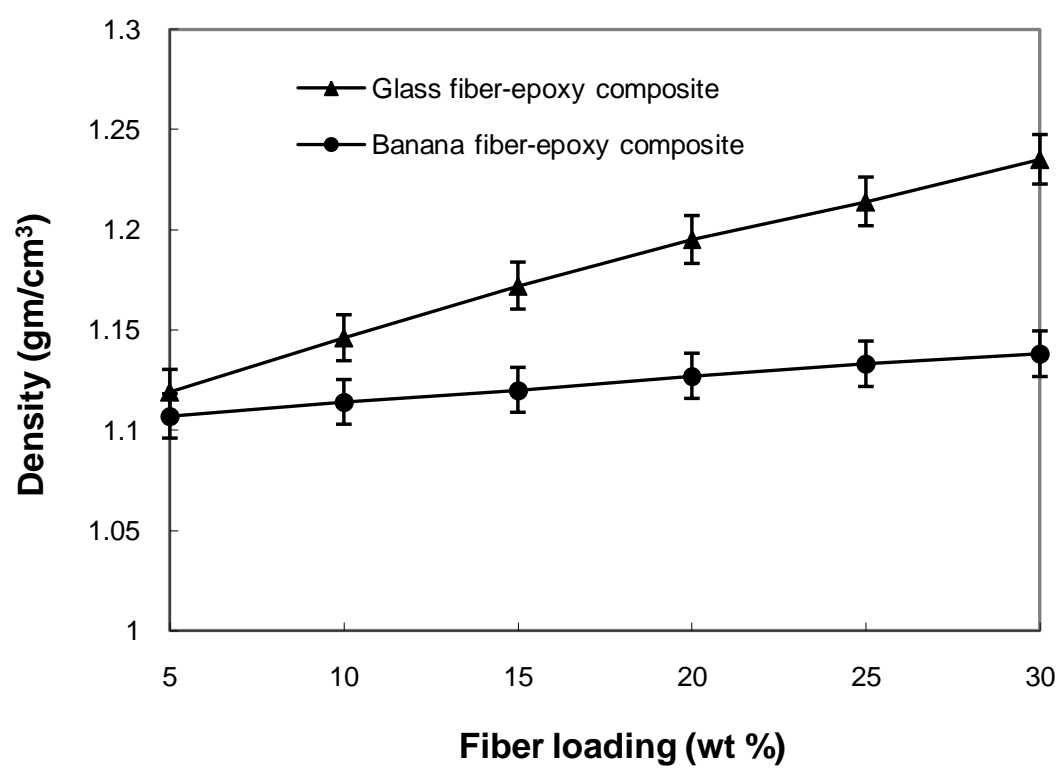

Comparison of experimental densities of both sets of composites

Micro-hardness

Hardness is considered as one of the most important factors that govern the wear resistance of any material. 


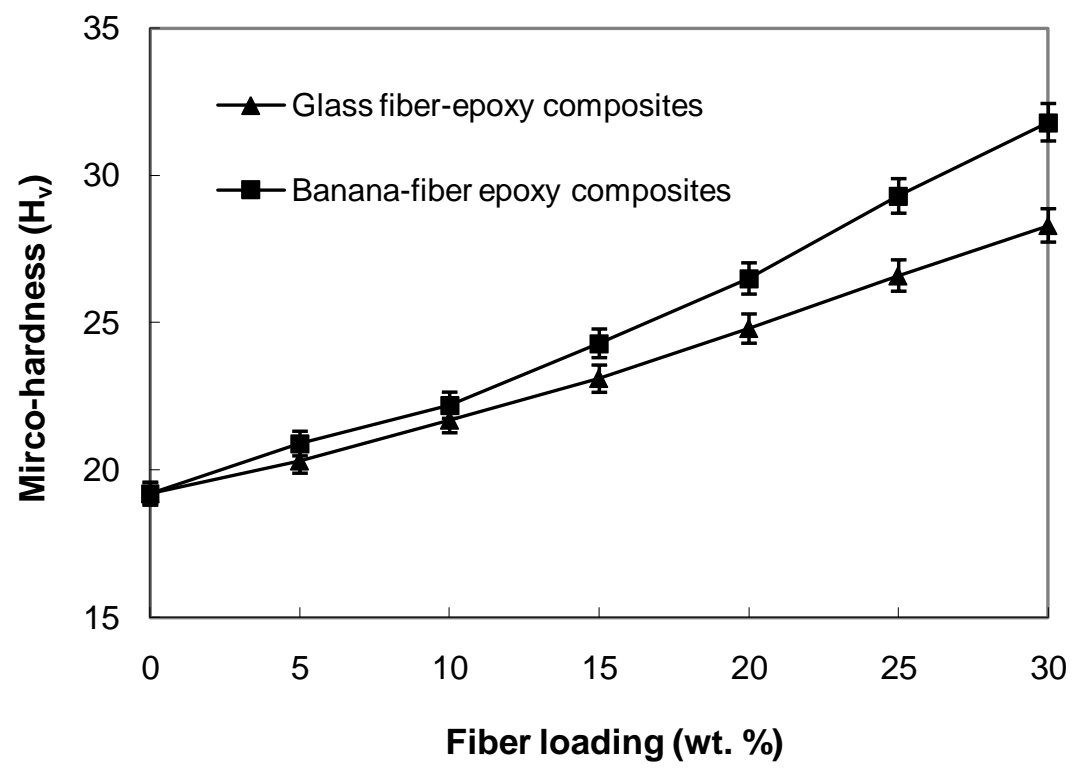

Effect of fiber loading on micro-hardness of epoxy composites

Tensile properties

It is well known that the strength properties of composites are mainly determined by the fiber content and the fiber strength.

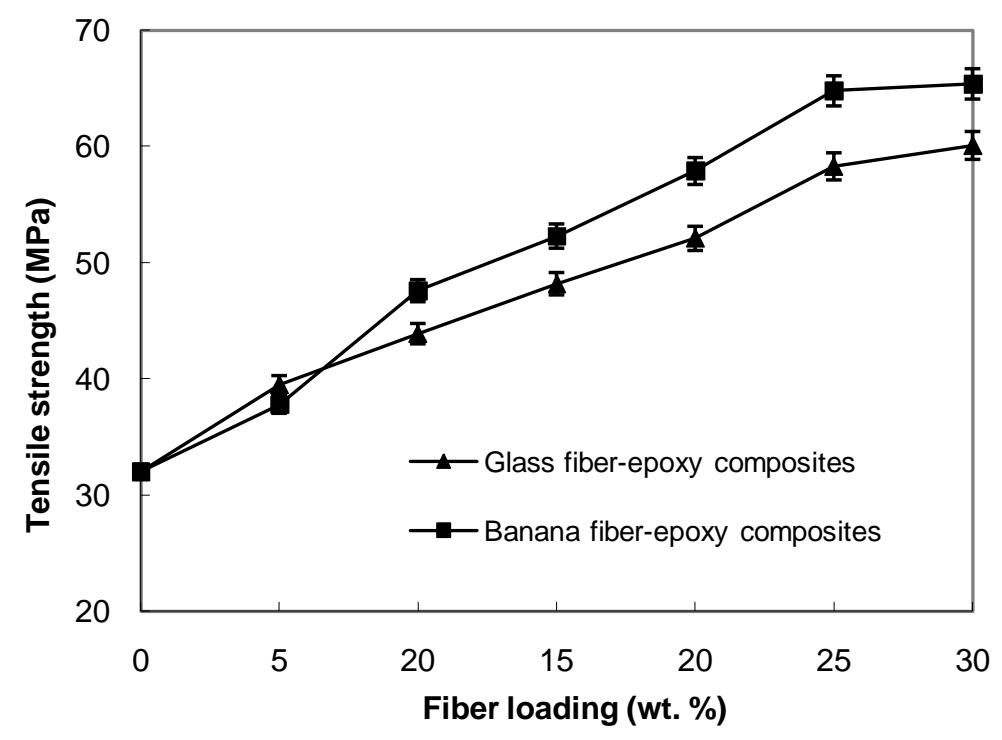

Effect of fiber loading on tensile strength of epoxy composites 


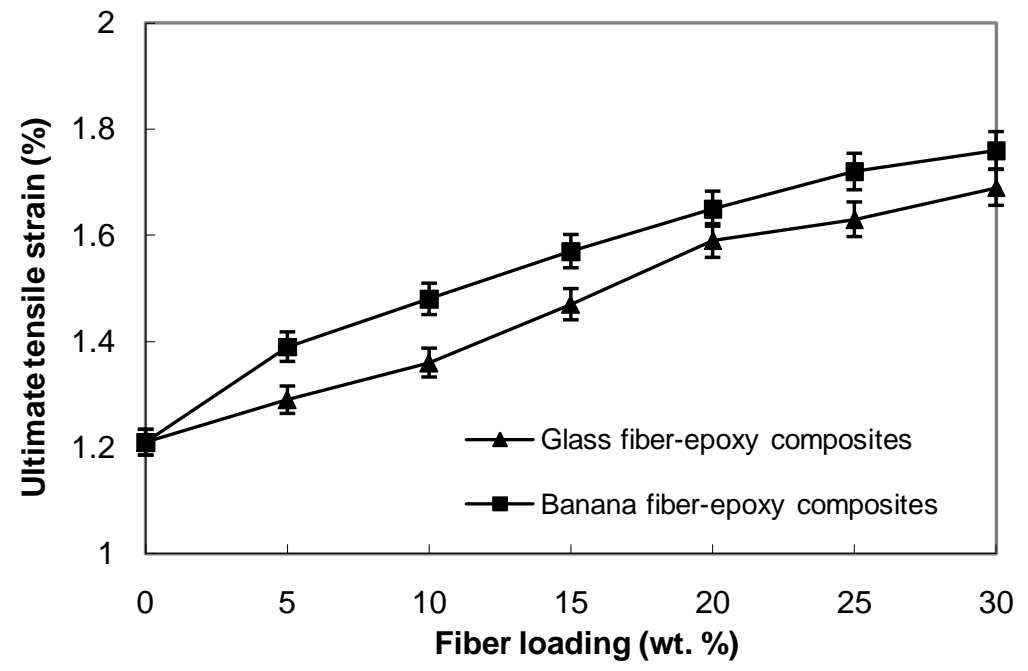

Effect of fiber loading on ultimate tensile strain of epoxy composites

\section{Flexural strength}

Composite materials used in structures are prone to fail in bending and therefore the development of new composites with improved flexural characteristics is essential.

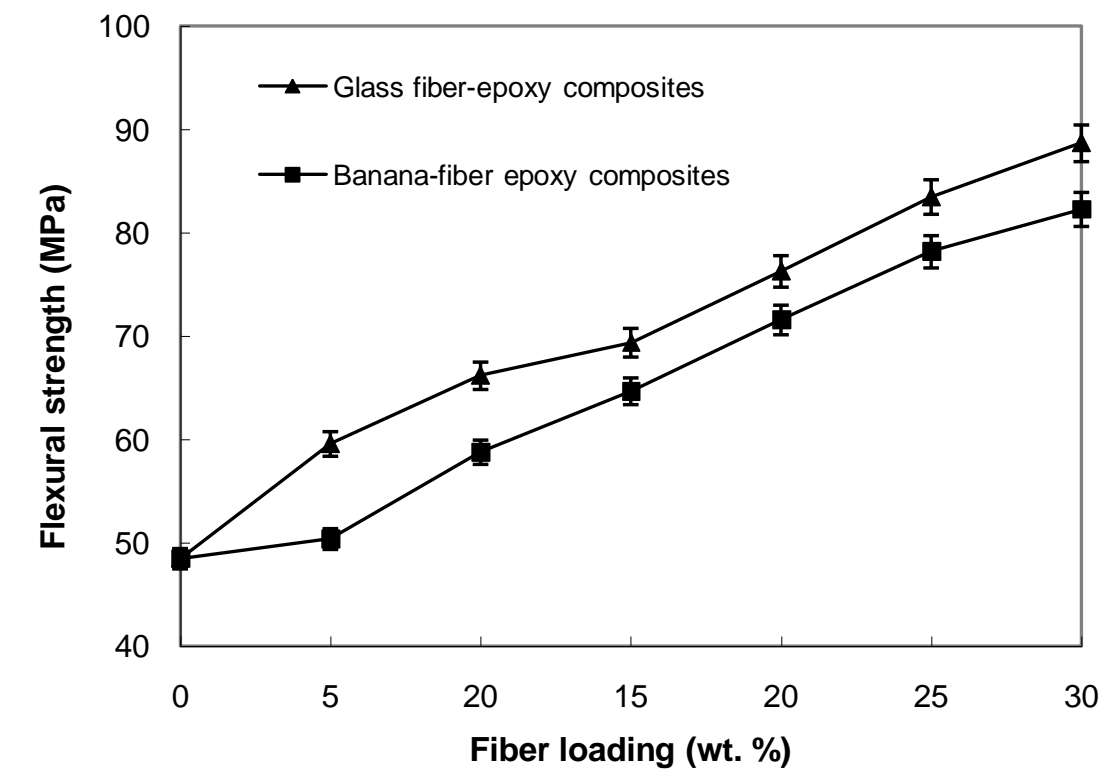

Effect of fiber loading on flexural strength of epoxy composites

\section{Impact strength}

The impact strength of a material is its capacity to absorb and dissipate energies under impact or shock loading. 


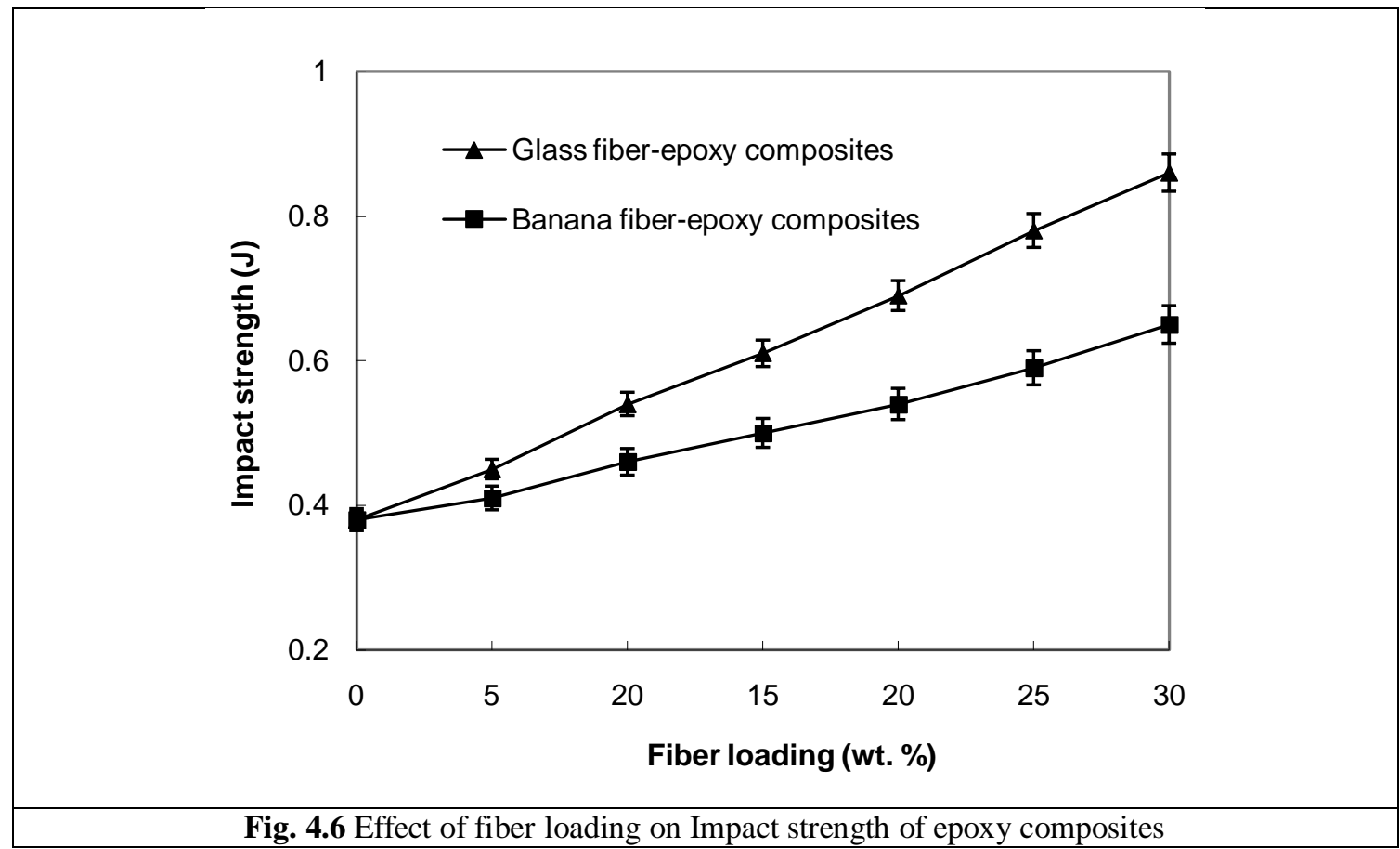

\section{TRIBOLOGICAL CHARACTERIZATION OF THE COMPOSITES}

This effects of different short fiber reinforcement on the erosion wear characteristics of glass fiber-epoxy composites and presents a comparison with those of a similar set of banana fiber-epoxy composites under identical test conditions.

\section{Erosion wear analysis of short glass fiber reinforced epoxy composites}

This part presents the analysis of erosion response of short glass fiber epoxy composites. The experiments have been carried out using Taguchi experimental design (L27 orthogonal array) given in Table 9.and the subsequent analysis of the test results is made using the popular software specifically used for design of experiment applications known as MINITAB 14.

\section{Taguchi experimental analysis}

The results of erosion experiments carried out according to the predetermined design on glass fiber-epoxy composites are presented in Table 12. This table provides the experimental erosion rate along with the signalto-noise ratio for each individual test run. Each value of the erosion rate is the average of three replications.

Table 12: Erosion wear test result with corresponding $\mathrm{S} / \mathrm{N}$ ratios using Taguchi method under different test conditions as per L27 orthogonal array for glass fiber epoxy composites

\begin{tabular}{|c|c|c|c|c|c|c|c|c|}
\hline $\begin{array}{l}\text { Test } \\
\text { run }\end{array}$ & $\begin{array}{c}\mathbf{A} \\
(\mathrm{m} / \mathrm{s})\end{array}$ & $\begin{array}{c}\text { B } \\
(\%)\end{array}$ & $\begin{array}{c}\mathrm{C} \\
\left({ }^{\circ} \mathrm{C}\right)\end{array}$ & $\begin{array}{c}\text { D } \\
\text { (Degree) }\end{array}$ & $\begin{array}{c}\mathbf{E} \\
(\mathrm{mm})\end{array}$ & $\begin{array}{c}\mathbf{F} \\
(\mu \mathrm{m})\end{array}$ & $\begin{array}{c}\mathbf{E}_{\mathbf{r}} \\
\text { (glass fiber-epoxy) } \\
(\mathrm{mg} / \mathrm{kg})\end{array}$ & $\begin{array}{c}\text { S/N ratio } \\
\text { (db) }\end{array}$ \\
\hline 1 & 30 & 0 & 40 & 30 & 60 & 300 & 306.522 & -49.7292 \\
\hline 2 & 30 & 0 & 50 & 60 & 70 & 450 & 513.043 & -54.2031 \\
\hline 3 & 30 & 0 & 60 & 90 & 80 & 600 & 604.512 & -55.6281 \\
\hline 4 & 30 & 15 & 40 & 60 & 70 & 600 & 384.783 & -51.7043 \\
\hline 5 & 30 & 15 & 50 & 90 & 80 & 300 & 564.186 & -55.0284 \\
\hline 6 & 30 & 15 & 60 & 30 & 60 & 450 & 400.012 & -52.0415 \\
\hline 7 & 30 & 30 & 40 & 90 & 80 & 450 & 333.945 & -50.4735 \\
\hline 8 & 30 & 30 & 50 & 30 & 60 & 600 & 182.608 & -45.2304 \\
\hline 9 & 30 & 30 & 60 & 60 & 70 & 300 & 263.043 & -48.4005 \\
\hline 10 & 40 & 0 & 40 & 60 & 80 & 450 & 339.135 & -50.6075 \\
\hline 11 & 40 & 0 & 50 & 90 & 60 & 600 & 530.434 & -54.4926 \\
\hline 12 & 40 & 0 & 60 & 30 & 70 & 300 & 573.225 & -55.1665 \\
\hline 13 & 40 & 15 & 40 & 90 & 60 & 300 & 208.695 & -46.3902 \\
\hline 14 & 40 & 15 & 50 & 30 & 70 & 450 & 236.013 & -47.4587 \\
\hline 15 & 40 & 15 & 60 & 60 & 80 & 600 & 286.956 & -49.1563 \\
\hline
\end{tabular}




\begin{tabular}{|l|l|l|l|l|l|l|l|l|}
\hline 16 & 40 & 30 & 40 & 30 & 70 & 600 & 210.288 & -46.4563 \\
\hline 17 & 40 & 30 & 50 & 60 & 80 & 300 & 411.957 & -52.2970 \\
\hline 18 & 40 & 30 & 60 & 90 & 60 & 450 & 339.135 & -50.6075 \\
\hline 19 & 50 & 0 & 40 & 90 & 70 & 600 & 245.652 & -47.8064 \\
\hline 20 & 50 & 0 & 50 & 30 & 80 & 300 & 539.131 & -54.6339 \\
\hline 21 & 50 & 0 & 60 & 60 & 60 & 450 & 665.568 & -56.4638 \\
\hline 22 & 50 & 15 & 40 & 30 & 80 & 450 & 260.869 & -48.3284 \\
\hline 23 & 50 & 15 & 50 & 60 & 60 & 600 & 297.289 & -49.4636 \\
\hline 24 & 50 & 15 & 60 & 90 & 70 & 300 & 252.174 & -48.0340 \\
\hline 25 & 50 & 30 & 40 & 60 & 60 & 300 & 477.228 & -53.5745 \\
\hline 26 & 50 & 30 & 50 & 90 & 70 & 450 & 321.738 & -50.1500 \\
\hline 27 & 50 & 30 & 60 & 30 & 80 & 600 & 443.478 & -52.9374 \\
\hline
\end{tabular}

The overall mean of the $\mathrm{S} / \mathrm{N}$ ratios is found to be $-50.9801 \mathrm{db}$ for glass fiber based composites. Figures 5.1 illustrate the effect of control factors on erosion rate of glass fiber epoxy composites. Analysis of the results leads to the conclusion that factor combination of A2 (Impact velocity:40m/sec ), B2 (Filler content: 15wt\%), $\mathrm{C} 1$ (Erodent temperature: $40^{\circ} \mathrm{C}$ ), D1 (Impingement angle: $30^{\circ}$ ), E2 (Stand-off distance: $70 \mathrm{~mm}$ ) and F3 (Erodent size: $600 \mu \mathrm{m})$ gives minimum erosion rate for glass fiber epoxy composites.

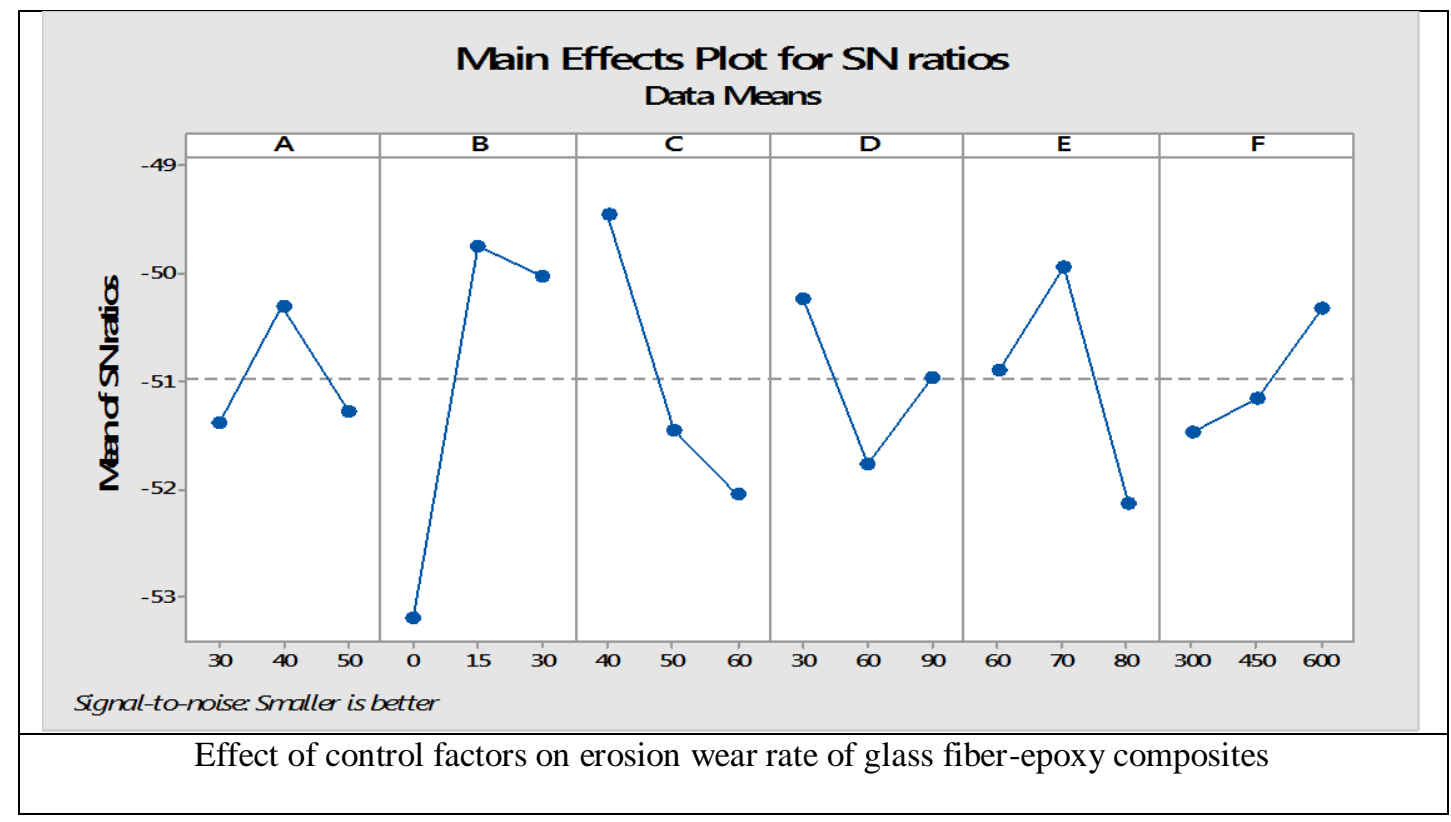

The $\mathrm{S} / \mathrm{N}$ ratio response is given in the Table 13., from which it can be concluded that among all the factors, glass fiber content in the composites is the most significant factor followed by erodent temperature, stand-off distance, impingement angle while the erodent size and impact velocity has the least or negligible significance on wear rate of glass fiber-epoxy composites.

Table 13.: Signal to noise ratio response table for erosion wear rate of glass fiber -epoxy composites

\begin{tabular}{|c|c|c|c|c|c|c|}
\hline Stage & A & B & C & D & E & F \\
\hline $\mathbf{1}$ & -51.38 & -53.19 & -49.45 & -50.22 & -50.89 & -51.47 \\
\hline $\mathbf{2}$ & -50.29 & -49.73 & -51.44 & -51.76 & -49.93 & -51.15 \\
\hline $\mathbf{3}$ & -51.27 & -50.01 & -52.05 & -50.96 & -52.12 & -50.32 \\
\hline Delta & 1.09 & 3.46 & 2.60 & 1.54 & 2.19 & 1.15 \\
\hline Rank & 6 & 1 & 2 & 4 & 3 & 5 \\
\hline
\end{tabular}

Erosion wear analysis of short banana fiber reinforced epoxy composites 
This part presents the analysis of erosion response of short banana fiber-epoxy composites. The experiments have been carried out using similar Taguchi experimental design that has been used for glass fiber-epoxy composites.

Taguchi experimental analysis

The results of erosion experiments carried out according to the predetermined design on banana fiber-epoxy composites are presented in Table 5.3.

Table 14: Erosion wear test result with corresponding S/N ratios using Taguchi method as per L27 orthogonal array for banana fiber epoxy composites

\begin{tabular}{|c|c|c|c|c|c|c|c|c|}
\hline $\begin{array}{l}\text { Test } \\
\text { run }\end{array}$ & $\begin{array}{c}\mathbf{A} \\
(\mathbf{m} / \mathbf{s})\end{array}$ & $\begin{array}{c}\text { B } \\
(\%)\end{array}$ & $\begin{array}{c}\mathrm{C} \\
\left({ }^{\circ} \mathrm{C}\right)\end{array}$ & $\begin{array}{c}\text { D } \\
\text { (Degree) }\end{array}$ & $\begin{array}{c}\mathbf{E} \\
(\mathbf{m m})\end{array}$ & $\begin{array}{c}\mathbf{F} \\
(\mu \mathrm{m})\end{array}$ & $\begin{array}{c}\mathbf{E}_{\mathrm{r}} \\
\text { (banana fiber-epoxy) } \\
(\mathrm{mg} / \mathrm{kg})\end{array}$ & $\begin{array}{c}\text { S/N ratio } \\
\text { (db) }\end{array}$ \\
\hline 1 & 30 & 0 & 40 & 30 & 60 & 300 & 225.128 & -47.0486 \\
\hline 2 & 30 & 0 & 50 & 60 & 70 & 450 & 199.995 & -46.0204 \\
\hline 3 & 30 & 0 & 60 & 90 & 80 & 600 & 375.245 & -51.4863 \\
\hline 4 & 30 & 15 & 40 & 60 & 70 & 600 & 225.130 & -47.0487 \\
\hline 5 & 30 & 15 & 50 & 90 & 80 & 300 & 301.500 & -49.5857 \\
\hline 6 & 30 & 15 & 60 & 30 & 60 & 450 & 205.830 & -46.2702 \\
\hline 7 & 30 & 30 & 40 & 90 & 80 & 450 & 202.851 & -46.1435 \\
\hline 8 & 30 & 30 & 50 & 30 & 60 & 600 & 526.352 & -54.4255 \\
\hline 9 & 30 & 30 & 60 & 60 & 70 & 300 & 211.865 & -46.5212 \\
\hline 10 & 40 & 0 & 40 & 60 & 80 & 450 & 416.665 & -52.3957 \\
\hline 11 & 40 & 0 & 50 & 90 & 60 & 600 & 337.500 & -50.5655 \\
\hline 12 & 40 & 0 & 60 & 30 & 70 & 300 & 436.528 & -52.8002 \\
\hline 13 & 40 & 15 & 40 & 90 & 60 & 300 & 247.508 & -47.8718 \\
\hline 14 & 40 & 15 & 50 & 30 & 70 & 450 & 228.330 & -47.1713 \\
\hline 15 & 40 & 15 & 60 & 60 & 80 & 600 & 273.520 & -48.7398 \\
\hline 16 & 40 & 30 & 40 & 30 & 70 & 600 & 187.512 & -45.4606 \\
\hline 17 & 40 & 30 & 50 & 60 & 80 & 300 & 480.000 & -53.6248 \\
\hline 18 & 40 & 30 & 60 & 90 & 60 & 450 & 316.666 & -50.0120 \\
\hline 19 & 50 & 0 & 40 & 90 & 70 & 600 & 262.501 & -48.3826 \\
\hline 20 & 50 & 0 & 50 & 30 & 80 & 300 & 585.287 & -55.3474 \\
\hline 21 & 50 & 0 & 60 & 60 & 60 & 450 & 483.330 & -53.6849 \\
\hline 22 & 50 & 15 & 40 & 30 & 80 & 450 & 366.660 & -51.2853 \\
\hline 23 & 50 & 15 & 50 & 60 & 60 & 600 & 325.500 & -50.2510 \\
\hline 24 & 50 & 15 & 60 & 90 & 70 & 300 & 375.213 & -51.4856 \\
\hline 25 & 50 & 30 & 40 & 60 & 60 & 300 & 495.225 & -53.8961 \\
\hline 26 & 50 & 30 & 50 & 90 & 70 & 450 & 233.325 & -47.3592 \\
\hline 27 & 50 & 30 & 60 & 30 & 80 & 600 & 412.500 & -52.3085 \\
\hline
\end{tabular}

\section{Taguchi experimental analysis}

The results of erosion experiments carried out according to the predetermined design on banana fiberepoxy composites are presented in Table 14. This table provides the experimental erosion rate along with the signal-to-noise ratio for each individual test run. Each value of the erosion rate is the average of three replications.

The overall mean of the $\mathrm{S} / \mathrm{N}$ ratios is found to be $-51.8247 \mathrm{db}$ for banana fiber based composites. Figures 5.2 illustrate the effect of control factors on erosion rate of glass fiber epoxy composites. Analysis of the results leads to the conclusion that factor combination ofA1 (Impact velocity: $30 \mathrm{~m} / \mathrm{sec}$ ), B2 (Filler content: $15 \mathrm{wt} \%$ ), $\mathrm{C} 1$ (Erodent temperature: $40^{\circ} \mathrm{C}$ ), D3 (Impingement angle: $90^{\circ}$ ), E2 (Stand-off distance: $70 \mathrm{~mm}$ ) and F2 (Erodent size: $450 \mu \mathrm{m})$ gives minimum erosion rate for banana fiber-epoxy composites 


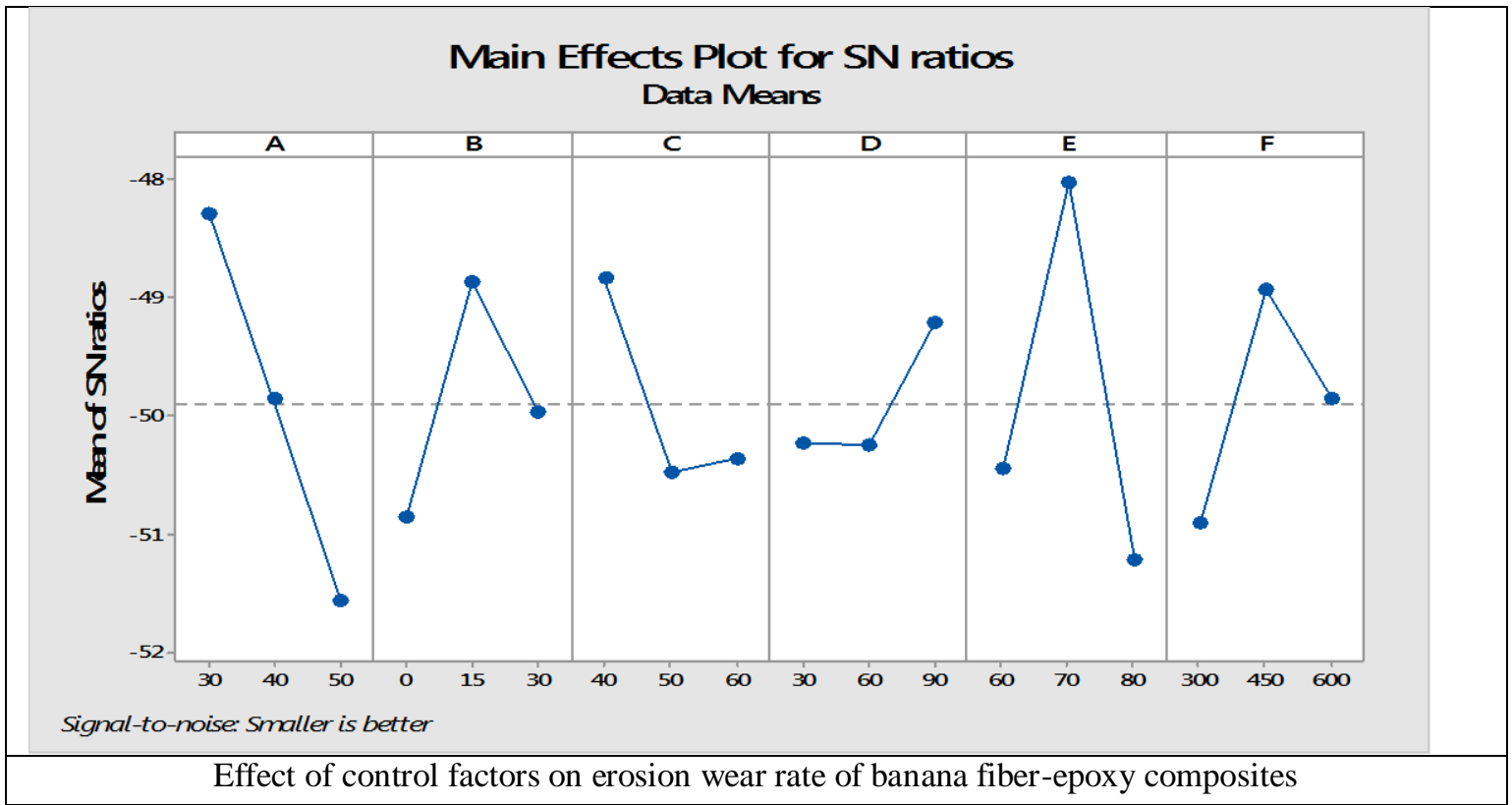

The S/N ratio response is given in the Table 15., from which it can be concluded that among all the factors, impact velocity of erodent is the most significant factor followed by stand-off distance, fiber loading, erodent size while erodent temperature, impingement angle has the least or negligible significance on wear rate of banana fiber-epoxy composites.

Table 15.: Signal to noise ratio response table for erosion wear rate of banana fiber -epoxy composites

\begin{tabular}{|c|c|c|c|c|c|c|}
\hline Stage & A & B & C & D & E & F \\
\hline $\mathbf{1}$ & -48.28 & -50.86 & -48.84 & -50.24 & -50.45 & -50.91 \\
\hline $\mathbf{2}$ & -49.85 & -48.86 & -50.48 & -50.24 & -48.03 & -48.93 \\
\hline $\mathbf{3}$ & -51.56 & -49.97 & -50.37 & -49.21 & -51.21 & -49.85 \\
\hline Delta & 3.27 & 2.00 & 1.65 & 1.03 & 3.19 & 1.98 \\
\hline Rank & 1 & 3 & 5 & 6 & 2 & 4 \\
\hline
\end{tabular}

\section{CONCLUSIONS}

This investigation has led to the following conclusions:

1) Successful fabrication of epoxy matrix composites reinforced with synthetic fiber as well as natural fiber is possible by simple hand-lay-up technique.

2) The density of the fabricated composites increases with increase in weight fraction and also increase in void content is reported with loading.

3) These composites possess very low amount of porosity even it is prepared by conventional hand lay-up technique, it also shows improved micro-hardness, tensile, compressive, flexural and impact strengths than those of the neat epoxy.

4) This study reveals that both the fibers possess good filler characteristics as it improves the erosion wear resistance of the polymeric resin. Erosion wear characteristics of these composites can be gainfully analyzed using a design-of-experiment approach based on Taguchi method. The analysis of experimental results shows that factors like glass fiber content, erodent temperature, stand-off distance, impingement angle, erodent size and impact velocity in sequence are the significance factor on wear rate of glass fiber-epoxy composites whereas impact velocity, stand-off distance, fiber loading, erodent size, erodent temperature, impingement angle in sequence are the significance factor on wear rate of banana fiber-epoxy composites.

5) It has been seen that glass fiber is being used as one of the major filler in polymeric resin for various application by various industries but from the present investigation it can be noticed that a natural fiber i.e. banana fiber is showing better properties when reinforced in epoxy resin as compared to well-known glass fiber. So finally it can be concluded that natural fiber (banana fiber) which is easily available in mass without paying any amount can successfully replace the costly and non-renewable synthetic fiber (glass fiber) in many applications. 


\section{REFERENCES}

[1] M. Jawaid, H.P.S. Abdul Khalil. "Cellulosic/Synthetic Fiber Reinforced Polymer Hybrid Composites: A Review”, Carbohydrate Polymers, Vol. 86, pp. 1-18, 2011.

[2] Gad Marom, Albert Reuveni and Daniel Cohn, "Stiffness Variability and Stress-Dependent Elastic Response of Synthetic Fiber-Reinforced Composites for Biomedical Applications", Biomaterials, Vol. 14, No. 2, 1993.

[3] Jansons, J.O., Glejbol, K., Rytter, J., Aniskevich, A.N., Arnautov, A.K. \&Kulakov, V.L. "Effect Of Water Absorption, Elevated Temperatures And Fatigue on the Mechanical Properties of Carbon-FiberReinforced Epoxy Composites for Flexible Risers”, Mechanics of Composite Materials, Vol. 38(4), pp.299-310, 2002.

[4] Kutty, S. K. \&Nando, G. B. "Effect of Processing Parameters on the Mechanical Properties of Short Kevlar Aramid Fiber-Thermoplastic Polyurethane Composite Plastics", Rubber and Composites Processing and Applications, Vol.19 (2), pp.105-110, 1993.

[5] Cho, J., Chen, J. Y. \& Daniel, I. M. "Mechanical Enhancement of Carbon Fiber/Epoxy Composites by Graphite Nanoplatelet Reinforcement", Scriptamaterialia, Vol.56 (8), pp. 685- 688, 2007.

[6] Chauhan, S. R., Gaur, B. \&Dass, K. "Effect of Fiber Loading on Mechanical Properties, Friction and Wear Behaviour of Vinylester Composites Under Dry and Water Lubricated Conditions", International Journal of Material Science,Vol. 1(1), pp. 1-8, 2011. 